Reza Alipour ${ }^{1}$ (D) http://orcid.org/ 0000-0002-8821-0402

Yaghoob Foroutan ${ }^{2}$

Mahmoud Sharepour ${ }^{3}$ (1) http://orcid.org/ 0000-0002-1969-9419

University of Mazandaran

\title{
SOCIAL CAPITAL AND CHILDBEARING TENDENCIES WITH EMPHASIS ON GENERATIONAL DIFFERENCES (CASE STUDY: BABOL CITY) ${ }^{4}$
}

\begin{abstract}
Aim: The present study aims to investigate the effects of social capital components on childbearing tendencies with an emphasis on generational differences.

Method: The statistical population of this study is people aged 15 years and older in Babol city. Using Cochran's formula, 383 people were selected as the sample population and a multi-stage cluster sampling method was used. The research method, survey, and data collection tool was a researcher-made questionnaire whose validity was confirmed through face validity. The reliability of the items was obtained through Cronbach's alpha of 0.8 . Also, the theoretical framework of this study was a combination of theories of social capital and childbearing tendencies.

Findings: The results of the Pearson test indicated a statistically significant correlation between some variables of social capital and childbearing tendencies. Furthermore, the results of generation regression analysis on some independent variables (trust, support, and real social network) and research dependent variables showed that $23.7 \%$ of the changes in these variables could be explained by generations. Also, the results of social capital regression analysis on childbearing tendencies revealed a relationship between the variables of social trust, social support, and real social network. Among these three variables, social support was found to be the strongest predictor variable with a beta coefficient of 0.387 . The results of path analysis, like regression analysis, showed the effect of age, trust, support, and real social network variables on childbearing tendencies; in total, social support variable had the greatest overall effect on childbearing tendencies (0.492).
\end{abstract}

Keywords: social capital, childbearing tendencies, generational differences

1 Master of Sociology, University of Mazandaran, alipour.reza72@gmail.com.

2 Associate Professor of Social Demography, University of Mazandaran, y.foroutan@umz.ac.ir.

3 Professor of Sociology, University of Mazandaran, m.sharepour@umz.ac.ir.

4 Babol is one of the cities of Iran in Mazandaran province. 


\section{Introduction and Statement of the Problem}

One of the most important and tangible consequences of the spread of modernity and the process of globalization is the decrease in fertility rate and childbearing tendencies, which has become a global and very important social issue today. The trend of world fertility rate has increased from 2000 (2.96 means about 3 children) in 2020 to 2.1 ie about 2 children (United Nations 2020: 9). Besides that, an example of such a marked decrease is Iran which experienced a rapid decline in fertility in the late 1981s and during the 1992s and in 2001 reached fertility rate below the replacement level (Ghodrati et al. 2011). The emergence of such extensive changes has attracted the attention of many researchers and policymakers to the issue of fertility rate and a large part of the theoretical and experimental literature in reproductive health, social sciences, sociology, and other related fields focused on this issue. Besides, the effect of fertility rate on population growth can have a significant impact on socio-economic development and socio-human resources (Niazi et al. 2016: 70-71). Therefore, the tendencies of childbearing and fertility rate as two important categories in the field of demography, especially in recent decades, have been emphasized by a large number of demographers and social scientists, which are influenced by a set of social and cultural factors. While in the past most demographers focused on biological factors, attention to socio-economic and cultural factors has played an important role in explaining fertility rate and the tendency to have children in recent years. For example, culture can explain why individuals or societies that seem to be economically the same but are different in terms of customs and language, act differently in terms of demographics. Culture can explain why the population of a region behaves the same demographically over time, although their economic conditions change (Alipour et al. 2016: 108). Also, modern norms and values such as industrialization, urbanization expansion, educational developments, growing interest in employment, life expectancy improvement, etc., have washed away the previous notions based on the general Iranian proverb that "whoever gives teeth shall give bread as well". Childbearing, once considered a measure for the quantitative development of the family and for enhancing the family's economic strength and having a cheap and reliable labor force, has been replaced by the objective and tangible fact that every child added to the family institution is like a creature. Urban children are no longer regarded as a force to serve and support the family economy but are considered as a factor wasting material resources and a member who neither earns income nor adds to the family economy (Alipour et al. 2016: 109). On the other hand, due to the process of modernity and the rapid decline in fertility rate and fertility rates below the replacement level, which has increased from about 7 children to 1.8 children in 1980 since 2011 (Statistics Center of Iran 2016). In other words, the decision to have or not to have a child is not formed by chance, but the basis of this decision is the elimination or reduction of several perceived needs and strong dependence on the shared life experience of the couple (Ramezankhani 2013: 505). Therefore, the decision to have children and fertility rate is made at both macro and micro levels. The macro-level is related to government policies and the micro-level 
is related to couples' decisions in their life together. At the macro level, the importance of childbearing and population growth is so great that in recent years it has even led to changes in government strategies and policies. For example, the former director of the United Nations Population Division has acknowledged that the number of countries whose official and government policies have shifted toward increasing childbearing has quadrupled over the last four decades, with the number of such countries From 13 countries in 1975 to 56 countries in 2015; new examples include Germany, Spain, Australia, Italy, Iran, Turkey, Russia, Japan, South Korea, and France. Regarding Iran, the principle reason may be the sharp decrease in the fertility rateover the past three decades (Forootan, Karami 2016: 72). At the micro-level, the couple's decision to have a child in the process of living together is affected by their relationships and actions with family, friends, relatives, other couples, and childcare standards. Among these, one of the most important areas affected by the tendencies of childbearing and fertility rate is the discussion of social capital, i.e. social capital can act as a medium through which people learn a lot about population behaviors or take action (Rad, Thawabi 2015: 137). In other words, the comprehensiveness of social capital is such that it even affects demographic variables such as migration, fertility rate, life expectancy, and especially childbearing tendencies. Social capital refers to collective assets that facilitate action and help individuals achieve their goals (Ghodrati et al. 2011: 89). The central idea of social capital is that human beings are connected through a set of networks and tend to share common values with other members of these networks. Since these networks constitute a resource, they can be considered as a kind of capital builder (Noghani, Asgharpour 2008, as cited in Field 2009: 32). Membership in communication networks and a set of common values and common interests is the central core of the concept of social capital (Noghani, Asgharpour 2008: 33). Therefore, social capital creates a valuable resource in life for individuals and a kind of social capital is created to childbearing tendencies despite the social-supportive environment (Rad, Thawabi 2015). In other words, social capital focuses on human relationships existing in all aspects of human life, and increasing or decreasing it affects the tendencies of childbearing and pregnancy. For example, a number of studies (e.g. Firoozbakht et al. 2020) have shown a significant positive correlation between social capital and childbearing tendencies, i.e. increasing social capital will lead to an increase in the number of pregnancies and childbearing tendencies. Likewise, other studies (such as Kaveh Firooz et al. 2017; Rasoulzadeh Aghdam et al. 2016) focused on the effect of social capital components of trust, participation, and virtual social network on childbearing tendencies. However, no coherent research on social capital and childbearing tendencies has been conducted in the city of Babol. In general, the main purpose of this article is to investigate the effect of social capital components (social trust, social participation, social support, social networks) on childbearing tendencies. 


\section{Research Background}

Various researches in Iran and abroad have been done in relation to social capital and childbearing tendencies (Kalantari et al. 2010; Ghodrati et al. 2011; Sadeghi, Sarai 2016; Rasoulzadeh Aghdam et al. 2016; Abbasi Shavazi, Drahaki 2017; Firouzbakht et al. 2019; cf. Rogers, Kincaid 1981; Burt 1982; Valente et al. 1997; Hawe, Shiel 2000; Pevalin et al. 2001; Casterline 2001; Woolcock, Narayan 2000; Bühler, Fratczak 2004; Philipov et al. 2004; Rossier, Bernardi 2009; Di Giulio et al. 2012; Bernardi, Klarner 2014; van Leeuwen 2017).

However, a number of studies have addressed a number of components of social capital and childbearing tendencies, including: 1-Social Participation (Kalantari et al. 2010; Rasoulzadeh Aghdam et al. 2016; Kaveh Firooz et al. 2017), 2-Social Support (Sadeghi, Sarai 2016; Abbasi Shavazi, Drahaki 2017; Paulin et al. 2001; Boka et al. 2001; Philipov et al. 2004; Bühler, Fratczak 2004; Rossier, Bernardi 2009; Di Giulio et al. 2012; Bernardi, Klarner 2014), 3-Social Networks (Abbasi Shavazi, Drahaki 2017; Kaveh Firooz et al. 2017; cf. Casterline 2001; Bühler, Kohler 2004; Philipov et al. 2004; Bühler, Fratczak 2004; Bernardi, Klarner 2014).

Regarding the subject of the present study, it is necessary to mention the following points: First, regarding the effects of social capital on childbearing tendencies, it should be said that the volume of such research in our country is very small and limited, ie its history is less than a decade. Also, the proportion of such studies in foreign countries and at the global level is higher than our country, but in general it can be said that the volume of such studies is very small and limited. Secondly, regarding the tendencies of childbearing, it should be said that this range of researches has an acceptable frequency in our country and especially in the world. Third, research on social capital and childbearing tendencies has only pointed to some components, while the most important components of social capital affecting childbearing tendencies have not been considered.

\section{The Theoretical Framework}

Since the present study is interdisciplinary by nature and has a sociological perspective, an attempt has been made to use integrated theories to show different angles of childbearing tendencies and social capital. According to the theories put forward in social capital, it can be said that social capital is like a broad umbrella that encompasses all aspects of human economic and social life. Although some theorists of social sciences and sociology consider the social network as one of the dimensions of social capital, according to the author, the sum of this interaction and relationship in social capital can be called a social network because individuals constitutes groups, or in other words, networks of groups that cause interaction and communication based on this social capital. Thus, as stated, the interactions and connections that exist in this social network lead to learning and social impact over time. In other words, there are two important features in a social network: 
a) social learning b) social impact. Social learning emphasizes the role of information in reducing uncertainty. Social learning may reduce this uncertainty through social media about the experiences of other women or men. Therefore, the probability that a man and a woman are opposed to the risk of accepting and developing a pregnancy may change. The second aspect, social influence, goes beyond learning processes, that is, it allows the tendencies of women or men to be influenced and changed by those who interact with them According to Putnam, the factor that causes the efficiency and maintenance of this social network is the contacts and interactions or the social interaction of individuals.

On the other hand, in discussing childbearing tendencies, it can be mentioned that there are two important factors in childbearing tendencies: financial-economic cost and time spent (time and money that people spend for their children). The decision that individuals make about having children depends on the important question of whether or not having children limits their financial resources and wastes time. As a result, many people think that they can only spend for small families or delay having children until their economic situation is resolved, that is, people can only rely on limited resources (money) to fulfill their reproductive desires. Hence, if the achievement of reproductive goals becomes more costly or goals in other areas become more important, it reduces people's fertility rate. In general, about the relationship between social capital and childbearing tendencies it can be said that the tendencies and decision to have children of individuals or generations are taken in the form of this social capital or, in simpler language, social networks. In other words, individuals make these tendencies and decisions about having or not having children in their relationships and interactions with others. Therefore, social networks are an important core in these childbearing tendencies and decisions and play an important role. Hence, within the framework of these interactions and relationships, learning and social impact are formed. For example, if a person decides not to have children, usually in the form of relationships and interactions with friends, family, neighbors, etc., he learns from others (social learning).

Having children for some reasons reduces a person's financial resources and wastes his time i.e. this person could have spent his time to earn more without having a child who has been dedicated his income and time to despite having a child. On the other hand, in the course of interactions with others, other people can influence one's way of thinking and behaving (social impact), i.e. if a person keeps company with people who have a negative attitude towards childbearing and consider the child to be detrimental to the goal and peace, this can change attitudes toward thinking, behavior, and action of childbearing and pregnancy tendencies. For this reason, social learning and social impact are two very important features of social capital networks, or better yet, social networks that affect the childbearing tendencies of individuals or even generations. 


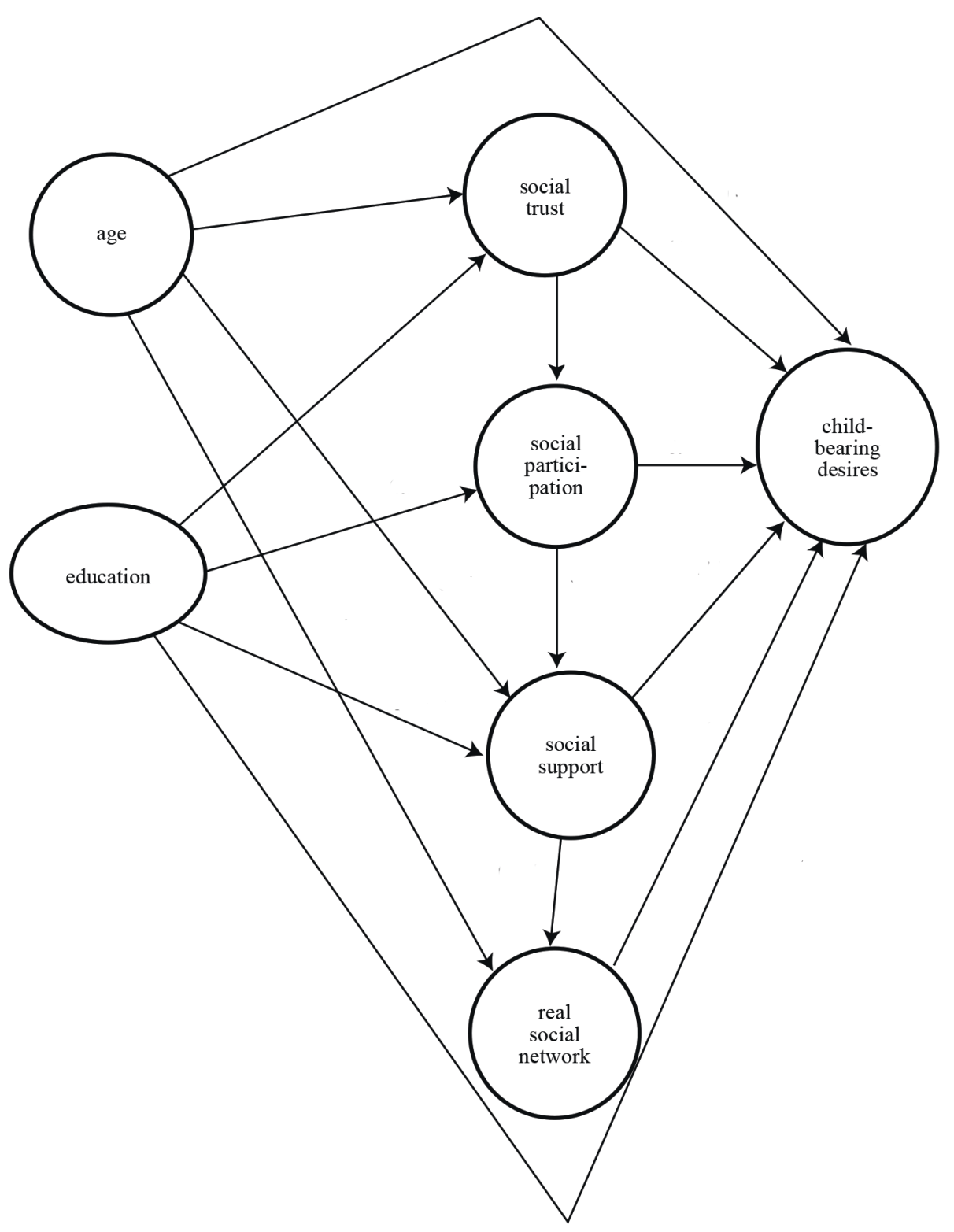

Figure 1. Theoretical model of research

Source: own elaboration. 


\section{Research Hypotheses}

1. There seems to be a significant relationship between social trust and childbearing tendencies.

2. It seems that there is a significant relationship between increasing social participation and childbearing tendencies.

3. There seems to be a significant relationship between social support and childbearing tendencies.

4. There seems to be a significant relationship between presence in a real social network and childbearing tendencies.

5. It seems that there is a significant relationship between the use of virtual social networks and childbearing tendencies.

\section{Research Methods}

The present study is a cross-sectional survey. The statistical population of this study consists of men and women aged 15 years and older living in urban and rural areas of Babol city. The population includes 383,260 , which are divided into four age groups in this study: first (15-29), second (30-39), third (40-49), and fourth (50 and above). Based on the Cochran sampling formula, the statistical sample size of the study was 383 people. In the present study, Cochran's formula was used to determine the sample size and the stepwise clustering sampling method was used to determine the sample. After collecting information through a questionnaire, the information was coded and extracted, and after entering the data into the computer, statistical analysis was performed using SPSS software. The Likert scale was used to measure the items, with 1 being the lowest number and 5 being the highest number. In general, in the present study, to ensure the assessment tool, first, the formal validity of the questionnaire questions was examined through a review in the literature and using the opinions of supervisors and experts in the field of research, and then to assess the reliability of the method Cronbach's alpha coefficient was used. Cronbach's alpha coefficient in this study was calculated to be 0.8 .

\section{The Theoretical and Operational Definition of the Variables}

\section{Social Capital}

Social capital is the networks and norms that enable people to act collectively (Woolcock, Narayan 2000: 225) or the kind of networks of relationships based on interpersonal and group social trust and individuals' interactions with institutions. It is the organization and social groups that are associated with solidarity and social cohesion and individuals and groups have the necessary support and energy to facilitate actions to achieve 
individual and collective goals (Abdollahi, Mousavi 2007: 221). In this study, social capital is divided into 4 sections: social trust, social participation, social support, and social networks.

\section{Social Trust}

Social trust implies socially acquired and accepted expectations and commitments relating individuals to each other and to organizations and institutions related to their social life and with a generalized relationship (Zahirinia et al. 2016: 95); or Social trust promotes higher levels of acceptance of volunteer work and reduces the cost of exchanges, thus streamlining cooperation (Sharipour et al. 2010). Therefore, in this study, social trust is divided into individual trust (interpersonal), institutional trust, and fundamental trust (generalized).

\section{A) Interpersonal Trust}

It means trusting family members, relatives, friends, and colleagues (Alipour et al. 2009: 121). Interpersonal trust is the result of face-to-face relationships between members of society and direct coexistence between interactors is one of their characteristics (Zahirinia et al. 2016: 95).

\begin{tabular}{|l|l|l|}
\hline Friendship can be trusted as in the past. & \multirow{2}{*}{ Interpersonal } & \multirow{2}{*}{ Social trust } \\
\hline How much can you trust your brother, sister and relatives? & & \\
\hline How much do you trust your neighbors? & & \\
\hline
\end{tabular}

\section{B) Institutional Trust}

It means optimism and confidence of individuals towards the performance of social institutions and groups (Alipour et al. 2009: 122). Therefore, the level of institutional trust is measured in terms of the type of people's evaluation of the employees of these institutions in the form of various departments, organs, and institutions that are associated with them in their daily lives (Alipour et al. 2009: 116).

\begin{tabular}{|l|l|l|}
\hline How much can MPs be trusted? & & \\
\cline { 1 - 1 } $\begin{array}{l}\text { How much can the judiciary } \\
\text { (courts, judiciary, etc.) be trusted? }\end{array}$ & Institutional & Social trust \\
\cline { 1 - 1 } $\begin{array}{l}\text { How honest and sincere are people } \\
\text { in dealing with each other? }\end{array}$ & & \\
\hline
\end{tabular}

C) Generalized Trust

It means having good suspicions about people in the community, regardless of whether they belong to ethnic or tribal groups. Therefore, in generalized trust, interaction and 
communication are promoted from within the group to intergroup (Zahirinia et al. 2016: 95).

\begin{tabular}{|l|l|l|}
\hline $\begin{array}{l}\text { Honest and sincere are employees in administrative and } \\
\text { organizational relationship. }\end{array}$ & \multirow{2}{*}{ Generalized } \\
\cline { 1 - 2 } $\begin{array}{l}\text { In our society, everyone is looking for their own work } \\
\text { rather than helping others. }\end{array}$ & Social trust \\
\cline { 1 - 2 } In general, how much can you trust strangers? & & \\
\hline
\end{tabular}

\section{Social Participation}

Social participation is a voluntary activity through which members of a community participate in the affairs of the neighborhood, city, and village and directly or indirectly participate in shaping social life (Kaveh Firooz et al. 2017). According to this research, social participation has been measured at both formal and informal levels.

\begin{tabular}{|l|l|l|}
\hline Sports courses. & \multirow{2}{*}{ Formal } & \\
\cline { 1 - 2 } Scientific and cultural associations. & & \\
\cline { 1 - 2 } $\begin{array}{l}\text { How useful do you find participation in political groups } \\
\text { and parties? }\end{array}$ & Social participation \\
\cline { 1 - 2 } How much do you participate in charities? & \\
\cline { 1 - 2 } $\begin{array}{l}\text { How much do you find useful in participating in family } \\
\text { or friendship loan funds? }\end{array}$ & \\
\cline { 1 - 2 } $\begin{array}{l}\text { Have you ever been consulted about holding religious } \\
\text { programs? }\end{array}$ & & \\
\hline
\end{tabular}

\section{Social Support}

Social support is said to help important people (Nabavi et al. 2009: 11). In other words, social support means the support that a person receives from family, friends, organizations, and other people (Tamnaeifar, Mansouri Nik 2013: 70). Social support in this study is divided into three parts: instrumental support, informational support, and emotional support.

\section{A) Instrumental Support}

It refers to the material, objective, and real help received by an individual from others (Riahi et al. 2010). In other words, instrumental support means having access to financial and service resources in hardships and difficulties (Abdolmaleki, Nasiri 2016: 104). 


\begin{tabular}{|l|l|l|}
\hline $\begin{array}{l}\text { When there is a financial need, there is someone special to help } \\
\text { me. }\end{array}$ & Instrumental & Social support \\
\hline In times of trouble, my friends give me time. & & \\
\hline There are people who can help me with some activities. &
\end{tabular}

B) Information Support

Information support means that individuals obtain their essential information through social interaction with others (Riahi et al. 2010). In other words, individuals can obtain the information they need to understand the situation (Abdolmaleki, Nasiri 2016: 104).

\begin{tabular}{|l|l|l|}
\hline Some people offered me solutions to the problem. & \multirow{2}{*}{ Informational } & $\begin{array}{l}\text { Social sup- } \\
\text { port }\end{array}$ \\
\cline { 1 - 1 } Some people provide information to help me overcome the problem. & & \\
\hline Some people tell me the ways to solve the problem.
\end{tabular}

\section{C) Emotional Support}

Emotional support means having the necessary skills to get help from others when dealing with difficulties (Abdolmaleki, Nasiri 2016: 104).

\begin{tabular}{|l|l|l|}
\hline Some people are by my side to deal with problems. & \multirow{3}{*}{ Emotional } & \multirow{2}{*}{ Social support } \\
\cline { 1 - 1 } Some people comfort me and encourage me to face the problem. & \\
\hline Some people listen to me when I talk about my personal problems. & \\
\hline
\end{tabular}

\section{Social Networks}

The social network is a set of actors and the relationships between them (Katz et al. 2004). In this study, the social network is divided into two parts: a) real social network, which includes social relations and the amount of travel with others is considered a century (face to face relationships), b) unreal social network which is the same as cyberspace.

\begin{tabular}{|l|l|l|}
\hline \multirow{3}{*}{$\begin{array}{l}\text { Social } \\
\text { network }\end{array}$} & \multirow{2}{*}{$\begin{array}{l}\text { Social relationships, } \\
\text { real (face to face) }\end{array}$} & Parents (if you do not live with them) \\
\cline { 3 - 3 } & & Neighbors \\
\cline { 3 - 3 } & & Acquaintances (relatives \\
\hline & Cyberspace & Brother or sister \\
\hline & & Satellite networks \\
\hline & & Whats App \\
\hline & & Facebook \\
\hline & & Istagram \\
\hline & & Internet (various sites/email/Gmail) \\
\hline
\end{tabular}




\section{Generation}

From Bals' point of view, generation is a generational decade, i.e. every ten years a new narrative of generations is told or generations express a new narrative of themselves (Niazi, Nasrabadi 2007). According to Baker, a generation is a group of people who were born at a certain time interval; groups that coincided with a historical event are also called the generation of that event, like those who experienced war (Fathi, Motlagh 2011:2). Demographers have also used a special meaning in measuring generation called "generational period". In this view, generation means the sequence of people through the movement of age layers (Niazi, Nasrabadi 2007). Therefore, in this study, the meaning of generation is the age group of ten years.

\section{Childbearing Tendencies}

Desire or tendency means a combination of cognition and perception, feeling, and readiness to perform an action. Desire to have children means the desire to have children socially and biologically in the family (Kalantari et al. 2010). In this study, this variable was measured by the indicators of the ideal number of children and the item of cultural belief in childbearing.

\begin{tabular}{|l|l|l|}
\hline $\begin{array}{l}\text { How many children do you think } \\
\text { each family should have? }\end{array}$ & The ideal number of children & \multirow{2}{*}{ Childbearing tendencies } \\
\hline $\begin{array}{l}\text { Some believe that "whoever gives } \\
\text { teeth, gives bread" means that God } \\
\text { will provide for the children5. }\end{array}$ & $\begin{array}{l}\text { The expression of cultural belief in } \\
\text { childbearing }\end{array}$ & \\
\hline
\end{tabular}

\section{Research Findings}
A) Brief Description

Table 1. Percentage distribution of respondents' childbearing tendencies in terms of social trust

\begin{tabular}{|l|l|l|l|l|l|}
\hline \multicolumn{1}{|c|}{ Total } & $\begin{array}{c}3 \text { children and } \\
\text { more }\end{array}$ & 2 children & 1 child & No children & Social trust \\
\hline 100.0 & 41.7 & 49.1 & 8.3 & 0.9 & Very much \\
\hline
\end{tabular}

5 According to the religious and cultural beliefs of the Iranian people, having children is associated with many blessings and sustenance (refers to the Creator and Provider). 


\begin{tabular}{|l|l|l|l|l|l|}
\hline 100.0 & 33.3 & 46.7 & 16.7 & 3.3 & Much \\
\hline 100.0 & 13.3 & 15.7 & 57.8 & 13.3 & To some extent \\
\hline 100.0 & 4.8 & 8.9 & 75.0 & 10.7 & Low \\
\hline- & 14.5 & 30.3 & 31.6 & 23.7 & Very little \\
\hline 100.0 & 23.5 & 31.9 & 34.7 & 9.9 & Total \\
\hline 383 & 90 & 122 & 133 & 38 & Frequency \\
\hline
\end{tabular}

Source: own elaboration.

Table 2. Percentage distribution of respondents' childbearing tendencies in terms of social participation

\begin{tabular}{|c|c|c|c|c|c|}
\hline Total & $\begin{array}{l}3 \text { children and } \\
\text { more }\end{array}$ & 2 children & 1 child & No children & $\begin{array}{c}\text { Social } \\
\text { participation }\end{array}$ \\
\hline 100.0 & 47.4 & 21.1 & 26.3 & 5.3 & Very much \\
\hline 100.0 & 14.9 & 37.6 & 36.3 & 10.9 & Much \\
\hline 100.0 & 26.3 & 34.3 & 29.3 & 10.1 & To some extent \\
\hline 100.0 & 33.3 & 28.6 & 38.1 & 0.0 & Low \\
\hline - & - & - & - & - & Very little \\
\hline 100.0 & 23.5 & 31.9 & 34.7 & 9.9 & Total \\
\hline 383 & 90 & 122 & 133 & 38 & Frequency \\
\hline
\end{tabular}

Source: own elaboration.

Table 3. Percentage distribution of respondents' childbearing tendencies in terms of social support

\begin{tabular}{|c|c|c|c|c|c|}
\hline Total & $\begin{array}{c}3 \text { children and } \\
\text { more }\end{array}$ & 2 children & 1 child & No children & Social support \\
\hline 100.0 & 86.7 & 0.0 & 6.7 & 6.7 & Very much \\
\hline 100.0 & 33.3 & 35.1 & 26.3 & 5.3 & Much \\
\hline 100.0 & 9.1 & 61.6 & 23.2 & 6.1 & To some extent \\
\hline 100.0 & 6.8 & 2.3 & 86.4 & 4.5 & Low \\
\hline 100.0 & 0.0 & 0.0 & 10.0 & 9.0 . & Very little \\
\hline 100.0 & 23.5 & 31.9 & 34.7 & 9.9 & Total \\
\hline 383 & 90 & 122 & 133 & 38 & Frequency \\
\hline
\end{tabular}

Source: own elaboration. 
Table 4. Percentage distribution of respondents' childbearing tendencies according to the real social network

\begin{tabular}{|l|l|l|l|l|l|}
\hline \multicolumn{1}{|c|}{ Total } & \multicolumn{1}{|c|}{$\begin{array}{c}\text { children and } \\
\text { more }\end{array}$} & \multicolumn{1}{|c|}{ 2 children } & \multicolumn{1}{|c|}{ No child } & \multicolumn{1}{c|}{$\begin{array}{c}\text { Real social } \\
\text { network }\end{array}$} \\
\hline 100.0 & 86.7 & 0.0 & 6.7 & 6.7 & Very much \\
\hline 100.0 & 33.3 & 35.1 & 26.3 & 5.3 & Much \\
\hline 100.0 & 9.1 & 61.6 & 23.2 & 6.1 & To some extent \\
\hline 100.0 & 6.8 & 2.3 & 86.4 & 4.5 & Low \\
\hline 100.0 & 0.0 & 0.0 & 10.0 & 9.0. & Very little \\
\hline 100.0 & 23.5 & 31.9 & 34.7 & 9.9 & Total \\
\hline 383 & 90 & 122 & 133 & 38 & Frequency \\
\hline
\end{tabular}

Source: own elaboration.

Table 5. Percentage distribution of respondents' childbearing tendencies according to the virtual social network

\begin{tabular}{|c|c|c|c|c|c|}
\hline Total & $\begin{array}{c}3 \text { children and } \\
\text { more }\end{array}$ & 2 children & 1 child & No children & $\begin{array}{c}\text { Virtual social } \\
\text { network }\end{array}$ \\
\hline 100.0 & 40.0 & 13.3 & 26.7 & 20.0 & Very much \\
\hline 100.0 & 16.9 & 36.9 & 33.8 & 12.3 & Much \\
\hline 100.0 & 15.4 & 42.3 & 35.9 & 6.4 & To some extent \\
\hline 100.0 & 32.8 & 31.3 & 31.3 & 4.5 & Low \\
\hline - & - & - & - & - & - \\
\hline 100.0 & & 31.9 & 34.7 & 9.9 & Total \\
\hline 383 & 90 & 122 & 133 & 38 & Frequency \\
\hline
\end{tabular}

Source: own elaboration.

In this study, 53.87 percent of the study population were men, and 46.2 percent were women. According to marital status, single people represented 19.8 percent and married people 74.9 percent of the population, respectively. The highest percentage of the respondents' educational group was related to the bachelor's degree group (31.6). In terms of residence, 53.8 percent lived in the city and 46.2 percent lived in the village. The highest percentage in terms of employment status was allocated to the group of employees (60.6) and the lowest percentage to the group of students (10.7). In summary, according to the results of descriptive tables and analyzing the effects of social capital components on childbearing tendencies it can be said that for this purpose, by changing the different levels of social trust, we see a difference in the tendency of the childbearing pattern. For example, the highest tendency to have children at the level of very high social trust for the one-child pattern $(41.0 \%)$ was about $\left(\frac{1}{3}\right)$ means one third and the highest tendency at the level of very low social trust, was the pattern of two children $(42.3 \%)$; this can be due to the fact that for different levels of participation and social 
support (too much to too little), there is a difference in the tendency to have a pattern of childbearing. In other words, the increase in different levels of participation and social support affects the tendency to have high and low childbearing patterns. For example, in the presence of very high participation and social support, the highest tendency is to have a pattern of three children and more (i.e. $47.4 \%$ and $86.7 \%$ ), and in the level of low participation and social support, the highest tendency is related to the pattern of one child (i.e. $38.1 \%$ and $90.0 \%$ ), but at different levels of the real social network, close to $\left(\frac{1}{3}\right)$ means one third the most inclination is to the pattern of two children. Also, according to the different levels of the virtual social network, the tendency to have a pattern of childbearing is different, that is, from very high to very low levels of measurement, it increases or decreases the tendency to have children.

Table 6. Percentage distribution of generational differences according to childbearing tendencies

\begin{tabular}{|l|l|l|l|l|l|}
\hline \multicolumn{7}{|c|}{ Total } & $\begin{array}{c}\text { 3 children and } \\
\text { more }\end{array}$ & \multicolumn{1}{|c|}{2 children } & 1 child & No children & \multirow{2}{*}{ Age category } \\
\cline { 1 - 5 } 100.0 & 10.7 & 26.8 & 46.6 & 16.1 & $15-29$ \\
\hline 100.0 & 15.1 & 45.3 & 32.6 & 7.0 & $30-39$ \\
\hline 100.0 & 30.0 & 33.3 & 28.6 & 7.9 & $40-49$ \\
\hline 100.0 & 54.3 & 20.0 & 20.0 & 5.7 & $\begin{array}{l}50 \text { years and } \\
\text { older }\end{array}$ \\
\hline 383 & 90 & 122 & 133 & 38 & Frequency \\
\hline
\end{tabular}

Source: own elaboration.

Table 7. Percentage distribution of generational differences in terms of social trust

\begin{tabular}{|l|l|l|l|l|l|l|}
\hline \multicolumn{1}{|c|}{ Total } & \multicolumn{1}{|c|}{ Very low } & \multicolumn{1}{|c|}{ Low } & \multicolumn{1}{c|}{$\begin{array}{c}\text { To some } \\
\text { extent }\end{array}$} & \multicolumn{1}{c|}{ Much } & \multicolumn{1}{c|}{ Very much } & $\begin{array}{c}\text { Age cate- } \\
\text { gory }\end{array}$ \\
\hline 100.0 & 0.0 & 12.5 & 51.8 & 26.8 & 8.9 & $15-29$ \\
\hline 100.0 & 0.0 & 8.9 & 58.1 & 17.4 & 16.3 & $30-39$ \\
\hline 100.0 & 0.0 & 15.9 & 46.0 & 20.6 & 15.9 & $40-49$ \\
\hline 100.0 & 0.0 & 5.7 & 42.9 & 22.9 & 28.6 & 50 years and \\
\hline 383 & 20 & 71 & 148 & 92 & 52 & Frequency \\
\hline
\end{tabular}

Source: own elaboration. 
Table 8. Percentage distribution of generational differences in terms of social participation

\begin{tabular}{|l|l|l|l|l|l|l|}
\hline Total & Very low & \multicolumn{1}{|c|}{ Low } & $\begin{array}{c}\text { To some } \\
\text { extent }\end{array}$ & \multicolumn{1}{|c|}{ Much } & \multicolumn{1}{c|}{ Very much } & $\begin{array}{c}\text { Age } \\
\text { category }\end{array}$ \\
\hline 100.0 & - & 5.4 & 46.6 & 29.2 & 7.1 & $15-29$ \\
\hline 100.0 & - & 8.1 & 46.5 & 36.0 & 9.3 & $30-39$ \\
\hline 100.0 & - & 9.5 & 33.3 & 49.2 & 4.9 & $40-49$ \\
\hline 100.0 & - & 14.3 & 37.1 & 42.9 & 5.7 & $\begin{array}{l}50 \text { years and } \\
\text { older }\end{array}$ \\
\hline 383 & - & 31 & 165 & 146 & 31 & Frequency \\
\hline
\end{tabular}

Source: own elaboration.

Table 9. Percentage distribution of generational differences by social support

\begin{tabular}{|l|l|l|l|l|l|l|}
\hline Total & Very low & \multicolumn{1}{|c|}{ Low } & \multicolumn{1}{|c|}{$\begin{array}{c}\text { To some } \\
\text { extent }\end{array}$} & Much & Very much & $\begin{array}{c}\text { Age cate- } \\
\text { gory }\end{array}$ \\
\hline 100.0 & 8.9 & 21.4 & 30.4 & 28.6 & 10.7 & $15-29$ \\
\hline 100.0 & 1.2 & 18.6 & 51.2 & 22.1 & 7.0 & $30-39$ \\
\hline 100.0 & 4.8 & 17.5 & 44.4 & 19.0 & 14.3 & $40-49$ \\
\hline 100.0 & 2.9 & 14.3 & 28.6 & 28.6 & 25.7 & $\begin{array}{l}50 \text { years } \\
\text { and older }\end{array}$ \\
\hline 383 & & 76 & 153 & 91 & 47 & Frequency \\
\hline
\end{tabular}

Source: own elaboration.

Table 10. Percentage distribution of generational differences by real social network

\begin{tabular}{|l|l|l|l|l|l|l|}
\hline Total & Very low & \multicolumn{1}{|c|}{ Low } & $\begin{array}{c}\text { To some } \\
\text { extent }\end{array}$ & \multicolumn{1}{|c|}{ Much } & Very much & $\begin{array}{c}\text { Age cate- } \\
\text { gory }\end{array}$ \\
\hline 100.0 & 1.8 & 39.3 & 8.9 & 19.6 & 30.4 & $15-29$ \\
\hline 100.0 & 1.2 & 19.8 & 14.0 & 17.4 & 47.7 & $30-39$ \\
\hline 100.0 & 0.0 & 17.5 & 14.3 & 28.6 & 39.7 & $40-49$ \\
\hline 100.0 & 0.0 & 5.7 & 17.1 & 31.4 & 45.7 & $\begin{array}{l}50 \text { years and } \\
\text { older }\end{array}$ \\
\hline 383 & 4 & 96 & 50 & 79 & 154 & Frequency \\
\hline
\end{tabular}

Source: own elaboration. 
Table 11. Percentage distribution of generational differences by virtual social network

\begin{tabular}{|c|c|c|c|c|c|c|}
\hline Total & Very low & Low & $\begin{array}{c}\text { To some } \\
\text { extent }\end{array}$ & Much & Very much & $\begin{array}{l}\text { Age cate- } \\
\text { gory }\end{array}$ \\
\hline 100.0 & - & 28.6 & 30.4 & 33.9 & 7.1 & $15-29$ \\
\hline 100.0 & - & 24.4 & 32.6 & 29.1 & 14.0 & $30-39$ \\
\hline 100.0 & - & 28.6 & 36.5 & 23.8 & 11.1 & $40-49$ \\
\hline 100.0 & - & 34.3 & 28.6 & 17.1 & 20.0 & $\begin{array}{l}50 \text { years and } \\
\text { older }\end{array}$ \\
\hline 383 & - & 114 & 120 & 94 & 55 & Frequency \\
\hline
\end{tabular}

Source: own elaboration.

According to the results of descriptive tables of generational differences between childbearing and social capital, we can almost say that the increase in age groups (youth, adults, middle-aged, elderly), increases childbearing tendencies. For example, in the youth age group, most of them were inclined to the pattern of two children (26.8\%) and most of the members of the elderly group were inclined to the pattern of three children and more (54.3\%). Considering using the virtual social network, the young age group used it the most and the older age group has the least use of the virtual social network. Also, generational differences in different levels of trust and social support were found to be moderate; all age groups had (somewhat) moderate trust and social support, but regarding the generational differences in social participation, it should be said that similarly half of the youth and adult age groups had moderate and almost similar social participation. The middle-aged and elderly age groups had high social participation. Besides, the generational difference of the real social network (except for the age group of young people who have a little real social network) was very high, i.e. the age groups had a very high real social network.

\section{Inferential Findings}

Pearson, regression, and path analysis tests were used to test the hypotheses in this study.

Table 12. Summary of social capital correlation test and childbearing tendencies

\begin{tabular}{|l|l|l|l|}
\hline \multicolumn{1}{|c|}{ Variables } & \multicolumn{1}{|c|}{$\begin{array}{c}\text { The correlation } \\
\text { coefficient }\end{array}$} & \multicolumn{1}{c|}{ Significance level } & \multicolumn{1}{c|}{$\begin{array}{c}\text { The coefficient } \\
\text { of determination }\end{array}$} \\
\hline Social trust & 0.611 & 0.000 & 0.99 \\
\hline Social participation & -0.038 & 0.499 & - \\
\hline Social support & 0.560 & 0.000 & 0.99 \\
\hline Real social network & 0.572 & 0.000 & 0.99 \\
\hline Virtual social network & -0.041 & 0.420 & \\
\hline
\end{tabular}

Source: own elaboration. 
According to the results shown in Table 12, there is a significant relationship between trust with childbearing tendencies, support with childbearing tendencies, and real social network with childbearing tendencies. Thus, there is a significant level of trust, support, and real social network $(0.000)$ with childbearing tendencies.

Table 13. Results of regression analysis test of social capital variables on childbearing tendencies

\begin{tabular}{|l|}
\hline Step by step method of entering variables \\
\hline Method $=$ Stepwise \\
\hline $\mathrm{R}=0.730$ \\
\hline $\mathrm{R}^{2}=0.610$ \\
\hline $\mathrm{R}^{2} \cdot$ Adj $=0.602$ \\
\hline S.E $=0.646$ \\
\hline ANOVA $=143.41$ \\
\hline Sig $=0.000$ \\
\hline
\end{tabular}

Source: own elaboration.

Table 14. Coefficients of regression analysis of social capital variables on childbearing tendencies

\begin{tabular}{|c|c|c|c|c|c|}
\hline Sig & $\mathrm{T}$ & S.E & Beta & B & $\begin{array}{l}\text { Independent } \\
\text { variables }\end{array}$ \\
\hline 0.000 & 2.269 & 0.144 & - & 1.330 & Constant \\
\hline 0.000 & 7.730 & 0.029 & 0.371 & 0.048 & Trust \\
\hline 0.000 & 8.631 & 0.034 & 0.387 & 0.779 & Support \\
\hline 0.000 & 5.785 & 0.033 & 0.267 & 0.457 & $\begin{array}{l}\text { Real social } \\
\text { network }\end{array}$ \\
\hline
\end{tabular}

Source: own elaboration.

In the regression equation of Tables 13 and 14, the relative importance of each independent variable in the description of the dependent variable is obtained by observing the values of the weights or regression coefficients. Among the five variables entered in the stepwise method, the variables of trust, participation, support, and real social network with standard coefficients $0.371,0.387$, and 0.267 , respectively, showed a significant relationship with childbearing tendencies. Also, the social support variable with standard coefficients of 0.387 is the strongest predictor of childbearing tendencies. To be more precise and simple, the variable of social support is the most influential variable on childbearing tendencies. Overall, according to these tables, it can be said that $60 \%$ of the changes in the dependent variable (childbearing tendencies) are explained by independent variables because the coefficient of determination is 0.602 . 
Table 15. Results of generation regression analysis test on social capital variables and childbearing tendencies

\begin{tabular}{|l|}
\hline Method $=$ Stepwise \\
\hline$R=0.730$ \\
\hline$R^{2}=0.237$ \\
\hline$R^{2}$. Adj $=0.203$ \\
\hline S.E $=0.924$ \\
\hline ANOVA $=51.79$ \\
\hline Sig $=0.000$ \\
\hline
\end{tabular}

Source: own elaboration.

Table 16. Coefficients of generation regression analysis test on social capital and childbearing tendencies

\begin{tabular}{|l|l|l|l|l|l|}
\hline \multicolumn{1}{|c|}{ Sig } & \multicolumn{1}{|c|}{ T } & \multicolumn{1}{|c|}{ S.E } & \multicolumn{1}{c|}{ Beta } & \multicolumn{1}{c|}{ B } & \multicolumn{1}{c|}{$\begin{array}{c}\text { Independent } \\
\text { variables }\end{array}$} \\
\hline 0.000 & 6.015 & 0.299 & 1.779 & -0.019 & Constant \\
\hline 0.000 & -0.305 & 0.004 & -0.001 & 0.043 & Trust \\
\hline 0.423 & -0.909 & 0.014 & -0.013 & 0.075 & Participation \\
\hline 0.000 & -1.248 & 0.047 & -0.073 & 0.036 & Support \\
\hline 0.040 & 0.610 & 0.045 & 0.028 & -0.086 & $\begin{array}{l}\text { Real social } \\
\text { network }\end{array}$ \\
\hline 0.539 & 1.783 & 0.035 & -0.081 & 0.035 & $\begin{array}{l}\text { Virtual social } \\
\text { network }\end{array}$ \\
\hline 0.000 & 5.430 & 0.190 & 0.399 & -0.019 & $\begin{array}{l}\text { Childbearing } \\
\text { desires }\end{array}$ \\
\hline
\end{tabular}

Source: own elaboration.

According to Tables 15 and 16, stepwise multivariate regression analysis has been used to study the simultaneous effect of generation variables on social capital variables and childbearing tendencies. Among the variables included in social capital, the components of trust, support, real social network, and childbearing tendencies were influential. According to the results of these tables, it can be said that $23.7 \%$ of the changes in social capital variables (trust, support, real social network) and childbearing tendencies can be explained by the variable of generations because the coefficient of determination is $0.237 \%$. Furthermore, among the variables included in social capital (social trust, social support, real social network) and step-by-step childbearing tendencies, the variables of trust, support, the real social network with standard coefficients $(-0.001,-0.072,0.028)$ and childbearing tendencies with standard coefficients (0.399) have shown a significant relationship with generations, among which, the strongest predictor variable of generations was the variable of childbearing tendencies with a standard coefficient of 0.399 . 
To be more precise and straightforward, the greatest influence of generations has been on the tendencies of childbearing.

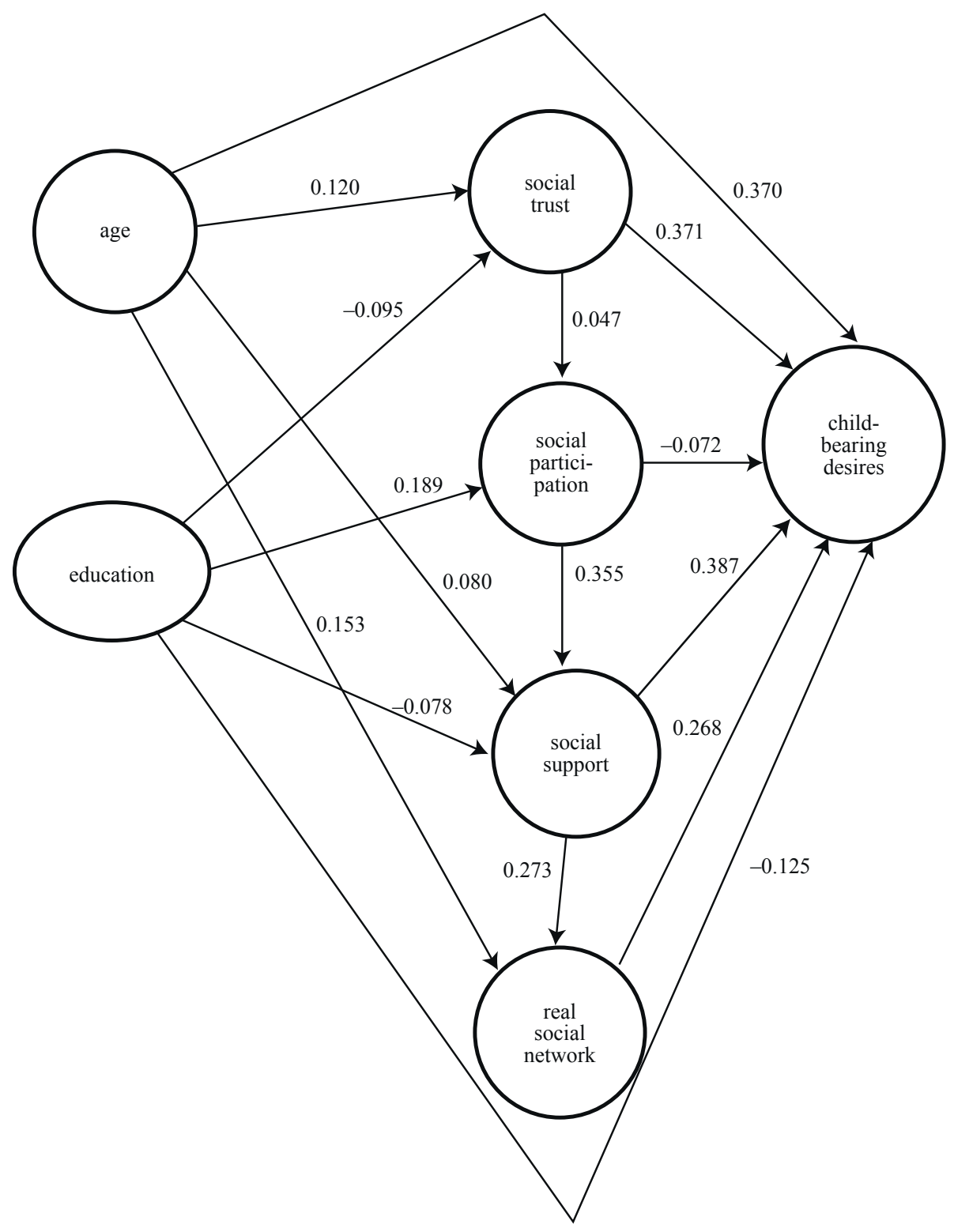

Figure 2. General diagram of social capital path analysis on childbearing tendencies

Source: own elaboration. 
Table 17. The extent of direct and indirect effects of independent variables on childbearing tendencies

\begin{tabular}{|l|l|l|l|}
\hline \multicolumn{2}{|c|}{ Types of effects } & \multirow{2}{*}{ Independent variables } \\
\cline { 1 - 3 } \multicolumn{1}{|c|}{ Total } & \multicolumn{1}{c|}{ Indirect } & \multicolumn{1}{c|}{ Direct } & \\
\hline 0.481 & 0.111 & 0.370 & Age \\
\hline-0.14 & -0.015 & -0.125 & Education \\
\hline 0.388 & 0.017 & 0.371 & Social trust \\
\hline-0.097 & -0.025 & -0.072 & Social participation \\
\hline 0.492 & 0.105 & 0.388 & Social support \\
\hline 0.268 & & 0.268 & Real social network \\
\hline
\end{tabular}

Source: own elaboration.

Table 17 indicates the direct and indirect effects of independent variables on childbearing tendencies. According to the data in the table, the column on direct effects shows that the standard coefficients of social support (0.387) have the highest impact on childbearing tendencies and categories. Next, the coefficients of the social trust standard (0.371), the standard coefficients of age (0.370), the standard coefficients of the real social network (0.268), the standard coefficients of education $(-0.125)$, and the standard coefficients of social participation $(-0.72)$ are allocated.

In the column related to indirect effects, we can see that the standard coefficients of age $(0.111)$ as the maximum effect, followed by the standard coefficients of social support (0.105), the standard coefficients of social participation $(-0.25)$, the standard coefficients of the real social network (0.036), standard coefficients of social trust (0.017) and standard coefficients of education $(-0.151)$.

Moreover, in the section related to the whole column, we can say that the standard coefficients of social support (0.492), the standard coefficients of age (0.481), the standard coefficients of social trust (0.388), the standard coefficients of real social network (0.268), the standard coefficients of education (0.14) and the standard coefficients of social participation (-0.97) are effective, respectively. In general, according to the whole column, it is evident that social support with standard coefficients (0.492) has been the most effective variable in analyzing the path of childbearing tendencies. In other words, the variable of social support was found to be the most influential variable on childbearing tendencies.

\section{Conclusion}

Fertility rate and the tendency to have children are important issues in the field of demography, and since this is important in families and is influenced by various demographic, social, and economic factors of each society, it is an interdisciplinary issue (Sadeghi, Sarai 2016: 2). One of the topics which have been the focus of attention in childbearing 
issues over the past few decades is the concept of social capital. Common indicators of social capital in research include trust, network, participation, support, connection, and so on. In other words, in recent research, social scientists have tried to establish a link between social capital and social network due to the interdisciplinary nature of fertility rate and childbearing tendencies. Today, in fertility rate research, for example, social networks are considered as one of the common indicators of social capital as an intermediary for learning population behavior and can create social capital related to fertility rate and childbearing tendencies, which in turn play a role in decreasing or increasing the number of their children and their desire to have children.

Therefore, according to the results obtained from the research hypotheses, we can conclude that there is a direct and significant positive relationship between social trust and childbearing tendencies. This means that as social trust increases, childbearing tendencies increase and with decreasing trust socially, the tendency to have children decreases as well. The results of regression analysis also show the effect of social trust with the standard coefficient of 0.371 . Besides, the research findings indicate the lack of effect of social participation on childbearing tendencies (non-confirmation of the second hypothesis), which is in contradiction with the research of Kaveh Firooz et al. (2017), Rasoulzadeh Aghdam et al. (2016), Kalantari et al. (2010). These studies have approved of the effect of social participation on the tendency to have children. Social participation is a voluntary activity through which members of a community participate in the affairs of the neighborhood, city, and village and directly or indirectly participate in shaping social life. The results of the generation regression analysis test on social participation with standard coefficients $(-0.013)$ and a significant level $(S=0.423)$ show that it does not affect social participation. Besides, research findings based on the relationship between social support and childbearing tendencies was consistent with the findings of Abbasi Shavazi and Drahaki (2017), Sadeghi and Sarai (2016), Bernardi and Klarner (2014), Dominguez, Watkins (2003), and Rossier, Bernardi (2009) (confirmation of the third hypothesis). To explain this hypothesis, it can be said that any social support means the support that a person receives from family, friends, organizations, and other people (Tamnaeifar, Mansouri Nik 2013: 70). Social support is one of the consequences and products of social capital, which includes the support of individuals and relatives, friends and neighbors, and includes three dimensions of instrumental (objective), informational, and emotional help. Objective or instrumental support indicates the availability of physical support. In this type of support, help is obtained from people who are close and intimate. Information support includes helping to understand an issue or problem. This type of support refers to information that a person can use against personal and environmental issues. Emotional support refers to resources associated with having people you can turn to for comfort and confidence. People who have sufficient emotional resources typically feel that they have others that they can turn to when dealing with problems. Therefore, according to the confirmed hypothesis, there is a direct and significant positive relationship between social support and childbearing tendencies, which means that as social support increases, childbearing tendencies increase, and as 
social support decreases, childbearing tendencies decrease. The results of regression analysis test revealed the effect of social support on childbearing tendencies, whose standard coefficients were equal (0.387) as well as the significant level $(S=0.000)$.

Also, in terms of the effect of generations on social support, it can be said that standard coefficients are equal to -0.722 and the significant level is equal to 0.000 , which indicates the effect of generation on social support. Besides, the research findings indicate the effect of real social networks on childbearing tendencies (confirmation of the fourth hypothesis). This finding is consistent with similar studies by Di Gillio et al. (2012) and Bernardi (2003), meaning that these studies have indirectly shown the impact of kinship networks on childbearing decisions. This means that individuals in the form of social groups form interactions that result from social learning and social impact (Bühler 2005). Another point is that the structure of social networks is very important because networks provide opportunities for information exchange. Structural conditions, in addition to maximizing the benefits of information, facilitate individualistic decision-making based on personal preferences and opportunities. In contrast, highly connected networks limit individuals' ability to make free decisions, innovate, or deviate from mold behavior (Bühler, Philipov 2005). Therefore, according to the confirmed hypothesis, there is a direct and significant positive relationship between presence in the real social network and childbearing tendencies. This means that as the presence in the real social network increases, so does the tendency to have children, and as the presence in the real social network decreases, so does the tendency to have children. The results of the regression analysis test show the effect of presence in the real social network on childbearing tendencies, whose standard coefficients were equal to 0.267 and the significant level was equal to $S=0.000$. Moreover, in terms of the effect of generations on presence in the real social network, the standard coefficient was equal to 0.028 and the significance level was equal to 0.040 , which indicates the effect of generations on the presence in the real social network. In fact, the social network is a set of actors and the relationships between them. Regarding the last hypothesis of the research, the results indicate that there is no significant relationship between the virtual social network and childbearing tendencies (not confirming the fifth hypothesis). The results of experimental studies of Kaveh Firooz et al. (2017); Mohammadi and Seifuri (2016), do not confirm this hypothesis, i.e. this research showed the effect of using virtual social networks on fertility rate and childbearing preference. The results of the generation regression analysis test on the use of the virtual social network with standard coefficients $(0.081)$ and significance level $(S=0.539)$ indicated that the use of virtual social network does not have any effects in this case.

In general, according to the research results, the following suggestions are made:

1. Establishing family institutes, holding life skills and parenting workshops for citizens.

2. Holding workshops and meetings on communication skills and marital skills.

3. Develop short-term, medium-term and long-term population policies to regulate births, not to limit, control and prevent population growth. 
4. Policy-making in the field of job creation for men and women, job security, social welfare and convergence between people and governance.

5. Improving the level of health of women and mothers, pregnancy care and packages proposed for childbearing by the governing system.

\section{References}

Abbasi Shavazi M.J., Drahaki A. (2017). The Effect of Social Media Mechanisms on the Intention of Women to Have Children in Urban Areas of Bushehr. "Bi-Quarterly Journal of Demographic Studies", 1 (4): 39-7.

Abdollahi M., Mousavi M. (2007). Social Capital in Iran: Current Situation, Future Perspectives and the Possibility of Transition. "Social Welfare Quarterly", 25 (6): 195-233.

Abdolmaleki S., Nasiri F. (2016). Determining the Relationship between Perceived Social Support and Quality of Life with the Mediating Role of Perceived Stress in Women Heads of Households in Sanandaj. "Applied Sociology", 64 (27): 99-116.

Alipour P. et al. (2009). Trust and Participation: A Study of the Relationship between Trust and Social Participation in Tehran. "Iranian Journal of Sociology", 2 (10): 109-135.

Bernardi L. (2003). Yearing. Channels of Social Influence on Reproductions. "Population Research and Policy Review": 527-555.

Bernardi L., Klarner A. (2014). Social Networks and Fertility. "Demographic Research", 30 (22): 461-670.

Bongaarts J. (2003). Completing the Fertility Transition in the Developing World: The Role of Educational Differences and Fertility Preferences. "Population Studies. A Journal of Demography", 57 (3): 321-335.

Bühler Ch. (2004). Additional Work, Family Agriculture, and the Birth of a First or a Second Child in Russia at the Beginning of the 1990s. "Population Research and Policy Review", 23: 259-289.

Bühler Ch. (2005). How Much do Inequalities of Income Matter for Fertility Intentions in Transitional Societies? Some Empirical Descriptions from Bulgaria. Paper presented at Annual Meeting of the Population Association of America, Philadelphia, April 2005.

Bühler Ch., Fratczak E. (2004). Learning from Others and Receiving Support: The Impact of Personal Network an Fertility Intention in Poland. "Max Planck Institute for Demographic Research": 1-26.

Bühler Ch., Kohler H.-P. (2004). Der Einfluss starker Beziehungen auf die Nutzung modern Kontrazeptiva in Kenia. "Zeitschrift für Soziologie”, 33: 5-25.

Bühler Ch., Philipov D. (2005). Social Capital Related to Fertility: Theoretical Foundations and Empirical Evidence from Bulgaria. "Vienna Yearbook of Population Research": 3, 53-81.

Buka S.L., Brennan R.T., Rich-Edwards J.W., Raudenbush S.W., Earls F. (2003). Neighborhood Support and the Birth Weight of Urban Infants. "American Journal of Epidemiology", 157: 1-8.

Burt R.S. (1982). Toward a Structural Theory of Action: Network Models of Social Structure, Perception, and Action. Academic Press, New York. 
Casterline J.B. (2001). Diffusion Processes and Fertility Transition: Introduction, in: Diffusion processes and fertility transition. Selected perspectives, ed. J.B. Casterline. National Academy Press, Washington, D.C.: 1-38.

Di Giulio P., Bühler Ch., Ette A., Fraboni R., Ruckdeschel K. (2012). Social Capital and Fertility Intentions: The Case of Italy, Bulgaria, and West Germany. „Vienna Institute of Demography Working Papers", 2: 1-27.

Dominguez S., Watkins C. (2003). Creating Networks Social Capital and Latin-American Income Mothers, "Social Problems", 5 (1): 111-135.

Fathi S., Motlagh M. (2011). Globalization and Generational Distance. "Quarterly Journal of Strategic Studies in Public Policy", 5 (2): 145-177.

Field J. (2009). A Social Capital Toolkit for Schools? Organisational Perspectives on Current Social Capital Research, in: Social Capital, Professionalism and Diversity, ed. J. Allan, J. Ozga, G. Smith (Studies in Inclusive Education, Vol. 5). Brill Publishers, Leiden: 21-35.

Firouzbakht M., Tirgar A., Hajian Tilaki K., Bakouei F., Nikpour M. (2019). Social Capital and Single Child in Employed Women. „Hakim Research Journal”, 22 (3 (86)), 241-248; https:// www.sid.ir/en/journal/ViewPaper.aspx?id=864081 (accessed: 20.07 .2020 ).

Forootan Y., Karami F. (2016). Patterns and Determinants of Childbearing Tendencies in Iran. "Letter of the Iranian Demographic Association", 21 (11): 71-100.

Ghodrati H. et al. (2011). Analysis of Social Capital and Fertility in Urban Areas of Sabzevar. “Quarterly Arid Regions Geographic Studies", 4 (1): 74-94.

Haug S. (2000). Soziales Kapital und Kettenmigration. Italienische Migranten in Deutschland. Leske + Budrich, Opladen.

Hawe P., Shiell A. (2000). Social Capital and Health Promotion. "Social Science \& Medicine", 51: 871-885.

Hosseini H., Begi B. (2012). Study of Reproductive Tendencies of Kurdish Women in Mahabad. "Strategic Studies of Women", 85 (15): 121-161.

Kalantari S. et al. (2010). Sociological Study of Childbearing Tendencies and Some Related Factors. "Applied Sociology", 37 (21): 83-104.

Katz N. et al. (2004). Small Group Research. "Sage Publication”, 35 (3): 306-333.

Kaveh Firooz Z. et al. (2017). The Effect of Social and Cultural Capital Components on Attitudes toward Childbearing. "Social Studies and Research in Iran", 1 (6): 143-1199.

Leeuwen M. van (2017). The Influence of Grandparental Related Social Capital on Fertility Intentions. The University of Utrekht, Utrekht, The Netherlands.

Mahmoudian H. (2000). Research in Theoretical Fields and Experimental Results of Migration and Reproduction. "Letter of the Social Sciences Association", 15 (16): 164-147.

Mohammadi N., Seifuri B. (2016). Sociological Study of Factors Affecting Female Fertility Preference. "Cultural-Educational Quarterly of Women and Family", 36 (11): 49-70.

Nabavi A. et al. (2009). Study of the Effect of Social Support on the General Health of the Elderly. "Iranian Journal of Sociology", 4 (80): 21-27.

Nasrollahi Vasti L., Beheshti M.B. (2016). Dynamic Analysis of the Role of Social Capital in the Development Process: An Interdisciplinary Approach. "Social Sciences Quarterly", 72 (25): 1-31. 
Niazi M. et al. (2016). Meta-analysis of Social Factors Affecting Fertility in Iran. "Quarterly Journal of Welfare Planning and Social Development", 29 (7): 69-118.

Niazi M., Nasrabadi M. (2007). Sociological Determination of the Phenomenon of Generation Gap and its Causes and Factors. "Domestic Policy", 2 (1): 185-227.

Noghani M., Asgharpour M., Ahmad R. (2008). A Comparative Study of Approaches and Indicators Used in Measuring Social Capital. "Management and Development Process", 68: 55-32.

Palloni A., Massey D.S., Ceballos M., Espinosa K., Spittel M. (2001). Social Capital and International Migration: A Test Using Information of Family Networks. "American Journal of Sociology”, 106 (5): 1262-1298.

Pevalin D.J., Wade T.J., Brannigan A., Sauve R. (2001). Beyond Biology: The Social Context of Prenatal Behaviour and Birth Outcomes. "Sozial- und Präventivmedizin", 46: 233-239.

Philipov D. (2003). Fertility in Times of Discontinuous Societal Change, in: Population of Central and Eastern Europe: Challenges and Opportunities, eds. I.E. Kotowska, J. Jozwiak. Statistical Publishing Establishment, Warsaw: 665-690.

Philipov D., Spéder Z., Billari F. (2004). Fertility Intentions and Their Timing: Theory and Evidence from Bulgaria and Hungary, Draft prepared for the PAA Meeting (Population Association of America) April 1-3, 2004, Boston; https://paa2004.princeton.edu/papers/40761 (accessed: 20.07.2020).

Rad F.., Thawabi H. (2015). Study of Tendency to Fertility and Related Social Factors. "Women and Family Studies", 1: 127-155.

Ramezankhani A. et al. (2013). Childbearing Decision Model. "Monitoring Quarterly": 515-505.

Rasoulzadeh Aghdam S. et al. (2016). Analysis of the Relationship between Social Capital and Lifestyle, "Socio-cultural Strategy", fifth year, 20: 135-107.

Riahi M.E. et al. (2010). Study of the Relationship between Social Support and Mental Health. "Social Welfare Quarterly", 10 (39): 85-121.

Rogers E.M., Kincaid D.L. (1981). Communication Networks. Free Press. New York.

Rossier C., Bernardi L. (2009). Social Interaction Effects on Fertility: Intention and Behaviours, „Revue européenne de Démographie”/ "European Journal of Population”, 25 (4): 467-485.

Sadeghi H.S., Sarai H. (2016). Factors Affecting the Tendency of Women to Have Children in Tehran. "Quarterly Journal of Welfare Planning and Social Development”, 7 (27): 1-31.

Sharipour M. et al. (2010). Study of the Situation of Social Capital among Young People with Emphasis on Gender. "Iranian Social Science Studies”, 33 (9): 135-153.

Statistics Center of Iran, General Population and Housing Census, 2016.

Szreter S., Woolcock M. (2004). Health by Association? Social Capital, Social Theory, and the Political Economy of Public Health. "International Journal of Epidemiology", 33: 650-667.

Tamnaeifar M., Mansouri Nik A. (2013). Predicting Life Satisfaction Based on Personality Traits, Social Support and Spiritual Well-being. "Quarterly Journal of New Psychological Research", 29 (8): 67-87.

United Nation, World Fertility and Family Planning 2020, Department of Economic and Social Capital Affairs: $1-4$. 
Valente T.W., Watkins S.C., Jato M.N., Straten A. van der, Tsitsol L.-P.M. (1997). Social Network Associations with Contraceptive Use among Cameroonian Women in Voluntary Associations. „Social Science \& Medicine”, 45: 677-687.

Woolcock M., Narayan D. (2000). Social Capital: Implications for Development Theory. "Research and Policy. The World Bank Research Observer": 49-225.

Zahirinia M. et al. (2016). Social Trust and Its Impact on Social Participation of Hormozgan University Students, "Hormozgan Research Journal”, 11: 86-136. 